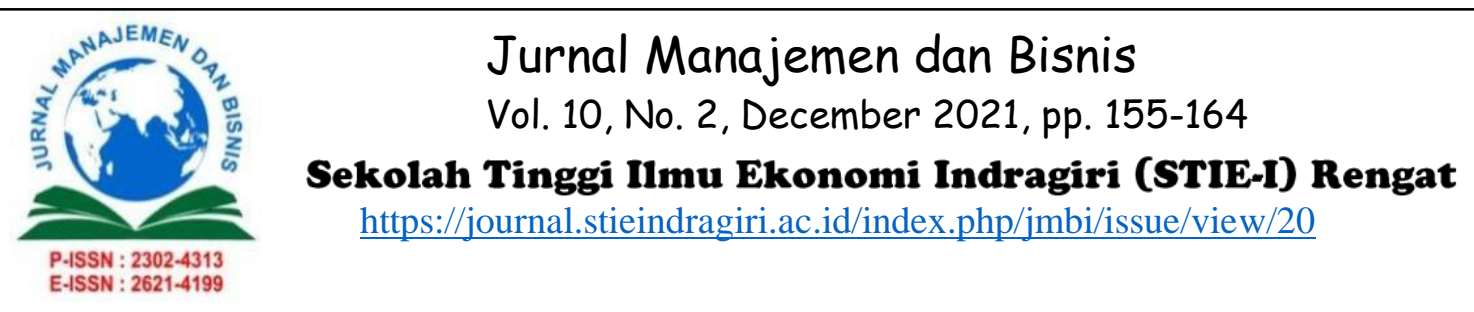

\title{
ANALYSIS OF CLASSIFICATION OF BUSINESS TYPES AND GOVERNMENT CONTRIBUTION TO THE DEVELOPMENT OF BUSINESSES MANAGED WITH DISABILITY IN GUNUNGKIDUL DISTRICT
}

\author{
Siti Afidatul Khotijah ${ }^{1)}$, Agustina Prativi Nugraheni' ${ }^{2)}$, Endang Kartini Panggiarti ${ }^{3)}$ \\ 1) 2) 3) Fakultas Ekonomi, Universitas Tidar \\ khotijah_afi@untidar.ac.id, devi.agustina@untidar.ac.id, endangkartini@untidar.ac.id \\ Submited: 2021.08.05 Reviewed: 2021.11.20 Accepted: 2021.12.31 \\ https://doi.org/10.34006/jmbi.v10i2.289
}

\begin{abstract}
This study aims to analyze groups of types of businesses run by people with disabilities in Gunungkidul Regency and analyze the role of the government in the development of businesses run by people with disabilities. This study uses purposive sampling where the main requirement is individuals with disabilities who have MSME businesses in Gunungkidul Regency. This research is a descriptive qualitative study. The type of data used in this study is primary data derived from interviews and observations of respondents. The results of this study indicate that the types of businesses run by people with disabilities in Gunungkidul Regency are mostly in the form of services (shaving, massage and sewing), handicrafts, printing and culinary services. The type of business carried out is in accordance with the advantages possessed by Gunungkidul Regency, namely the agricultural, industrial and service sectors. In addition, the government, represented by the Gunungkidul Regency MSME Service, has involved disabilities in the expo activities that were held, but people with disabilities expect more roles from the office for business assistance, starting from improving product quality, marketing to capital.
\end{abstract}

Keywords: type of business, leading sector, MSMEs, Disabilities

\begin{abstract}
ABSTRAK
Penelitian ini memiliki tujuan untuk menganalisis kelompok jenis usaha yang dijalankan disabilitas di Kabupaten Gunungkidul dan menganalisis peran pemerintah dalam perkembangan usaha yang dijalankan disabilitas. Penelitian ini menggunakan purposive sampling dimana syarat utamanya adalah individu difabel yang memiliki usaha UMKM di Kabupaten Gunungkidul. Penelitian ini adalah study kualitatif deskriptif. Jenis data yang digunakan di dalam penelitian ini adalah data primer yang berasal dari wawancara dan observasi kepada responden. Hasil dari penelitian ini menunjukkan bahwa jenis usaha yang dijalankan oleh disabilitas di Kabupaten Gunungkidul sebagain besar berupa jasa (jasa cukur, pijat dan jahit), kerajinan, percetakan dan kuliner. Jenis usaha yang dijalankan sudah sesuai dengan keunggulan yang dimiliki Kabupaten Gunungkidul, yaitu sektor pertanian, industri dan jasa. Selain itu, pemerintah yang diwakili Dinas UMKM Kabupaten Gunungkidul sudah melibaatkan disabilitas dalam kegiatan ekspo yang digelar, namun disabilitas mengharapkan peranan lebih dari dinas untuk pendampingan usaha, mulai dari peningkatan mutu produk, pemasaran hingga permodalan.
\end{abstract}

Kata kunci: jenis usaha, sektor unggulan, UMKM, Disabilitas

Vol. 10, No. 2, December 2021, pp. 155-164

https://doi.org/10.34006/jmbi.v10i2.289 


\section{INTRODUCTION}

Disability is a part of society that has certain characteristics. Persons with disabilities still experience discriminatory treatment. This treatment does not only come from the family environment but also from the community and government (Surwanti \& Hindasah, 2013). Currently, the government has not treated disability properly, such as many public facilities that are not accessible to persons with disabilities, education for persons with disabilities is still low, as can be seen from a large number of persons with disabilities who do not attend school, government, and private institutions employing persons with disabilities. disability, social rehabilitation centers for disability in Indonesia are still lacking, and social assistance provided by the government to persons with disabilities is also not evenly distributed. People with disabilities are increasingly marginalized and experience wider discrimination, both in family, community, and state life.

The number of problems above reflects that the management of disability in Indonesia to increase the level of disability welfare has not been implemented properly. Many studies have been conducted related to disability welfare including Surwanti (2014), Tjahjanti et al., (2018), and many other researchers. Previous research has focused more on the role of government in disability welfare. In addition, several researchers also highlighted the attitude of business owners or companies towards disability in recruiting their workforce. To support the economy, people with disabilities do not have to be workers in other companies, but people with disabilities can start a business as an owner. In this way, the disability group also contributes to the driving force of the nation's economy by becoming MSME business actors.

Micro, Small and Medium Enterprises (MSMEs) are drivers of economic stability that must be supported to continue to create added value (Rofiq \& Edward, 2019). MSMEs have a strategic and important role in the national economy. In the Indonesian economy, the existence of MSMEs which is quite dominant can be seen from various reliable data. The results of the study stated that as many as 52.1 million units or $99.9 \%$ of the total business units were the number of industries that were not small and evenly distributed in every economic sector. Employment is also one of the potentials of MSMEs. When compared to the same investment in large-scale businesses, each investment unit in the MSME sector can create more job opportunities. The MSME sector absorbs around $91.03 \%$ of the total workforce working in Indonesia. As much as 33\% of the total GDP is the contribution of SMEs in the formation of GDP. This figure has a significant contribution (Puspitaningtyas et al., 2013). The data proves that other countries can make Indonesia a potential market. This enormous potential has not been used by MSMEs for maximum development until now.

Each region has the authority and opportunity to make regulations that are by the regional potential to immediately improve regional economic development to increase community prosperity (Puspitaningtyas et al., 2013). The pattern of economic growth that each region has is different from other regions. Following the current period of regional autonomy, one of the important things is the determination of the leading sectors that serve as the basis for regional development planning. One area that has differences and uniqueness from other regions is Gunungkidul Regency. The four leading sectors are owned by Gunung Kidul Regency. The four leading sectors of Gunungkidul Regency are the agricultural sector, the building sector, the mining and quarrying sector, and the transportation and communication sector (Restiatun, 2009). These four sectors should be utilized by the community to improve the economy. One of the community groups that also have a contribution to regional development is the disability group.

Data obtained from Sakernas in February 2017, the National Working Age population with Disabilities amounted to 21,930,529 people. The total number of people with disabilities who enter the workforce is $11,224,673$ people or $51.18 \%$. Meanwhile, the disabled workforce currently working is $10,810,451$ people or $96.31 \%$ and the unemployed are 414,222 people or 
$3.69 \%$. This means that the number of people with disabilities who work is much greater than the number of people with disabilities who are not working or unemployed (Tjahjanti et al., 2018). With a large workforce, the greater the opportunity for people with disabilities to set up a business in the form of Micro, Small, and Medium Enterprises (MSMEs). When compared to Large Enterprises (UB), MSMEs are a business group that has the largest number and can also absorb a lot of workers (Putri, 2018). People with disabilities do not have to work for other people, but they can create jobs for others.

In this regard, the author will analyze how business practices carried out by persons with disabilities are associated with the leading sector of Gunungkidul Regency. The author will also analyze the role of the Gungkidul Regency government in developing the economy and businesses run by people with disabilities.

\section{LITERATURE REVIEW}

\section{Micro Small and Medium Enterprises}

Article 1 of the law of the Republic of Indonesia number 20 of 2008 concerning Micro, Small and Medium Enterprises (MSMEs), states that micro-enterprises are productive businesses owned by individuals and/or individual business entities that have the criteria for micro-enterprises as described in the law. this. While small businesses are productive economic businesses that stand-alone, also run by individuals or business entities. The business entity is not a subsidiary or not a branch of a company that is owned, controlled, or becomes a part either directly or indirectly of a medium or large business that meets the criteria of a small business as regulated in this Law. Meanwhile, medium-sized enterprises are productive economic enterprises that stand alone. This business is carried out by an individual or a business entity that is not a branch of a company that is owned, controlled, or becomes a direct or indirect part of another business, both on a small and large scale. This business is also not a subsidiary of other businesses. In addition, this business also has nothing to do with businesses whose net worth or annual sales results are as regulated by law (Putri, 2018).

MSMEs have a strategic role in economic development in Indonesia. One reason is that MSMEs are said to be the main drivers of economic development and job openings in rural areas (Y Hadi et al., 2017). MSMEs in Indonesia is currently the main magnet in the current economy (Rosita et al., 2017).

\section{Type of business}

Bank Indonesia is making efforts to develop MSMEs, one of which is by providing information based on research results on the Leading MSME Commodities/Products/Types of Business (KPJU) in an area, both Province and Regency and City. The development of MSMEs is driven by KPJU research which can be a source of useful information. The Central Statistics Agency (BPS) has published the Indonesian Standard Field Classification (KBLI) which is used as the basis for research on the MSME Leading KPJU based on the classification of the economic sector.

To be able to determine the policy of sectoral or multi-sectoral development patterns, an inventory of regional/community/regional potentials is required. This is done in the context of regional economic development efforts. One stage of the inventory or regional economic potential is to determine the potential, superior and superior products of the region in each subsector. According to Unkrich Satya Wacana Salatiga, what characterizes superior products are commodities that meet the requirements of local resource requirements, competitive position, and competitive potential as well as commodity linkages. The results of the analysis conducted on Mirathan (2013) explained that the things that became the basis for determining the KPJU were chosen as candidates for Livestock and Fisheries, Forestry and Plantations, Food Crops and Horticulture, Industry and Services and Trade. 


\section{Disability}

Law No. 4 of 1997 concerning Persons with Disabilities, Article 1 paragraph 1 states that persons with disabilities are anyone who has physical and/or mental disorders. These disorders can interfere with or become obstacles and obstacles for him to carry out activities properly. These disorders consist of several types, namely: people with mental disabilities, people with physical disabilities, and people with physical and mental disabilities. This definition is the current definition of a person with a disability or the definition of a disability problem.

Another definition is explained by Mulyono in (Arzul et al., 2019) which explains that the term persons with disabilities or the community refer to children with special needs or children with disabilities which can be interpreted as "children who are classified as disabled or with disabilities as well as potential and gifted children. ". In another opinion, according to Sunardi in Mumpuniarti (1999), there are four aspects of people with disabilities that are expressed in the identification process. These aspects are physical, psychological, social, and vocational aspects. Meanwhile, based on the disability law, the types of disabilities can be grouped into people with physical disabilities consisting of speech deaf (hearing and speech disorders), blind (visual impairments) and physically disabled (body disorders). While the mentally disabled, consisting of mentally retarded and tuna laras, there are types of people with physical and mental disabilities.

\section{RESEARCH METHOD}

The type of research used in this research is descriptive qualitative. Qualitative research is an approach or search to understand and explore a central phenomenon ( Cresswell in Palewa, 2013). Researchers conducted interviews with research participants, researchers, or participants by asking some general and rather broad questions to understand a central phenomenon. Disabilities in Gunungkidul Regency who are the perpetrators of Micro, Small and Medium Enterprises (MSMEs) are the objects of this research. This study uses human instruments as the instrument. According to Sudarwin (2002) in (Djaelani, 2013) I give the opinion that in qualitative research that uses researchers as instruments, it means that researchers carry out field work directly and mingle following activities with people being observed to collect data.

This study uses a collection technique with interviews and field observations so that the data is obtained in the form of primary and secondary data. Subjects directly interviewed. In addition, researchers also observed phenomena that occurred in the field to obtain secondary data. This qualitative research uses primary analysis with a brainwave approach. Researchers will go through 3 main stages to identify existing patterns to be able to find answers to the formulation of the problem. The patterns used are open coding, axial coding, and selective coding. The stage begins with coding from an unclear understanding in the form of a list of several relevant categories or called open coding. Next is tracking the links between the encoded data elements or called Axial Coding. Finally, the integration and filtering of categories are called Selective Coding (Sudira, 2009).

\section{ANALYSIS AND DISCUSSION}

\section{Summary of Dominant Respondent Profile}

The author looks at the current trend of respondents by compiling a summary of the respondent's profiles. Based on the results of open interviews filled out by 10 respondents with disabilities in Gunungkidul, the dominant respondent profiles in this study were as follows: 
Table 1.

Results of Respondent Profile Data

\begin{tabular}{|c|l|l|l|c|}
\hline Number & Name & Gender & Education & $\begin{array}{c}\text { Type of } \\
\text { Disability }\end{array}$ \\
\hline 1. & Hardiyo & Male & $\begin{array}{l}\text { Technical } \\
\text { High School }\end{array}$ & $\begin{array}{c}\text { Paraplegic } \\
\text { Quadriplegic) }\end{array}$ \\
\hline 2. & Mujiyana & Male & $\begin{array}{l}\text { Commercial } \\
\text { High School }\end{array}$ & $\begin{array}{c}\text { Quadriplegic } \\
\text { After Paralysis }\end{array}$ \\
\hline 3. & $\begin{array}{l}\text { Bagas } \\
\text { Wahyu } \\
\text { Nugroho }\end{array}$ & Male & $\begin{array}{l}\text { Vocational } \\
\text { High School }\end{array}$ & Foot Blind \\
\hline 4. & Maridi & Male & $\begin{array}{l}\text { Senior High } \\
\text { School }\end{array}$ & $\begin{array}{l}\text { Quadriplegic } \\
\text { (Paraplegic) }\end{array}$ \\
\hline 5. & Kristiadi & Male & $\begin{array}{l}\text { Senior High } \\
\text { School }\end{array}$ & Quadriplegic \\
\hline 6. & Saryono & Male & $\begin{array}{l}\text { Vocational } \\
\text { High School }\end{array}$ & Quadriplegic \\
\hline 7. & Sumiyati & Female & $\begin{array}{l}\text { Senior High } \\
\text { School }\end{array}$ & Quadriplegic \\
\hline 8. & $\begin{array}{l}\text { Anjar } \\
\text { Winarti }\end{array}$ & Female & $\begin{array}{l}\text { Junior High } \\
\text { School }\end{array}$ & Quadriplegic \\
\hline 9. & Sukarno & Male & $\begin{array}{l}\text { Junior High } \\
\text { School }\end{array}$ & Foot Blind \\
\hline 10. & Nasiyem & Female & No School & Blind \\
\hline
\end{tabular}

Based on the data that has been responded to by the respondents, the majority of people with disabilities in Gunungkidul who run businesses are male. Out of 10 respondents, only 3 women with disabilities run businesses. In terms of education, most of these disabilities are high school graduates (SMA) or equivalent. When viewed from the type of disability, almost all people with disabilities who run businesses experience physical disabilities. By the explanation to Law No. 8 of 2016, a person with a physical disability or physically disabled is someone who experiences impaired movement function, including paralyzed or stiff, amputation, cerebral palsy (CP), paraplegia, due to leprosy, due to stroke, and little people.

\section{Analysis of Types of Businesses run by Disability in Gunungkidul Regency}

According to (Rachbini, 2001), there are four conditions so that a certain sector becomes a priority sector, namely 1.) a large enough demand for the products produced by that sector, so that the growing movement develops rapidly due to the effect of the demand; 2.) the new production function shifts with the development of a wider capacity as a result of changes in technology that are adopted creatively; 3 .) both private and government, there must be an increase in re-investment of the results of the production of the priority sector; 4.) the sector can influence other sectors so that it must continue to grow (Puspitaningtyas et al., 2013).

Results Based on the analysis that has been carried out, obtained 10 (ten) cross-sectoral KPJUs based on the order of the weighted values of the respective KPJUs, as shown in Figure 1. Of the $10 \mathrm{KPJUs}$, there are 5 (five) leading KPJU sectors, namely the type of fish salting business, financial services savings and loans, business traders of shellfish aquaculture products, and fishing in the sea (Puspitaningtyas et al., 2013). Results Based on research 
conducted by Puspitaningtyas et al (2013), 10 Cross-Sectoral Commodities/products/Services (KPJU) that Have the Highest Weighted Scores of Cross-Sector Leading KPJUs in Tanjungbalai City are as follows:

\begin{tabular}{|c|l|l|l|}
\hline Number & \multicolumn{1}{|c|}{$\begin{array}{c}\text { Business Sector/Sub- } \\
\text { Sector }\end{array}$} & $\begin{array}{c}\text { Commodity/Product/Type } \\
\text { of Business }\end{array}$ & Weighted Score \\
\hline 1 & Industry & Fish Salting & 0.0553 \\
\hline 2 & Service & $\begin{array}{l}\text { Financial Services/Savings } \\
\text { and Loans }\end{array}$ & 0.0384 \\
\hline 3 & Trading & Fishery Products Trader & 0.0363 \\
\hline 4 & Fishery & Clam Cultivation & 0.0315 \\
\hline 5 & Fishery & Fishing in the Sea & 0.0308 \\
\hline 6 & Industry & Fish Meal Industry & 0.0296 \\
\hline 7 & Fishery & Fish Cultivation in Pond & 0.0280 \\
\hline 8 & Fruits & Banana & 0.0268 \\
\hline 9 & Trading & Agricultural Products Trader & 0.0241 \\
\hline 10 & Trading & Mini Market & 0.0236 \\
\hline & & & \\
\hline
\end{tabular}

Figure 1

10 business commodities/products/services (KPJU) across sectors

Based on the table above, the sector that plays the main role is the industrial sector, while research conducted by (Arifin \& Muta'ali, 2016) shows that the agricultural sector is the sector with the most and dominant role. Meanwhile, the mainstay sectors in some areas are the mainstay sectors of choice in some areas of Gunungkidul Regency, namely the Agriculture, Industry, and services and trade sectors. If it is related to the research above, the types of businesses run by persons with disabilities in Gunungkidul Regency are as follows:

Table 2.

Types of Business with Disabilities in Gunungkidul

\begin{tabular}{|c|l|l|c|}
\hline Number & \multicolumn{1}{|c|}{ Name } & \multicolumn{1}{|c|}{ Type of Business } & $\begin{array}{c}\text { Business } \\
\text { fields }\end{array}$ \\
\hline 1. & Hardiyo & Making a mat from patchwork & Craft \\
\hline 2. & Mujiyana & Padang cuisine restaurant \& catering & Culinary \\
\hline 3. & $\begin{array}{l}\text { Bagas } \\
\text { Wahyu } \\
\text { Nugroho }\end{array}$ & Screen printing \& clothing maker & Printing \\
\hline 4. & Maridi & Snack production & Culinary \\
\hline 5. & Kristiadi & Seamstress & service \\
\hline 6. & Saryono & Buying and selling birds + bird feed & Buy and sell \\
\hline 7. & Sumiyati & Sew & service \\
\hline 8. & Anjar winarti & Sew & service \\
\hline 9. & Sukarno & Barber & service \\
\hline 10. & Nasiyem & Massage & service \\
\hline
\end{tabular}

Table 2 above shows that the types of businesses run by people with disabilities in Gunungkidul Regency are very diverse. Several types of businesses are run, such as businesses in the fields of crafts, culinary, services, buying and selling, and many other types of businesses that are often run. From the respondents studied, it can be seen from the type of business that 
is run in handicrafts, buying and selling and also services. Some of the services provided, such as tailors, barbers, and massages, are the most widely used business sectors for persons with disabilities in Gunungkidul Regency. To Arifin \& Muta'ali, (2016) research, the sectors that are mostly run by disabilities are in the fields of industry, trade, and services.

According to Indonesian law number 20 of 2008 explains the definition of microenterprises are productive businesses owned by individuals and/or individual business entities that meet the criteria for micro-enterprises as regulated in this law. Considered as job openings and the main driver of development in rural areas, MSMEs are considered to have an important role in economic development in Indonesia (Y Hadi et al., 2017). With the role of MSMEs as an economic driver, MSMEs should be able to create jobs for the community. However, when viewed from the field of business run by persons with disabilities in Gunungkidul Regency, the businesses that are run are individual and have not created many job opportunities for other communities.

Most of the service sectors that are run are still running the business and have not tried to transmit and open up the field for other people. With the abilities that have been possessed by disabilities, they should be developed to open up job opportunities for the community, such as opening courses for the services they have, such as opening barber services, sewing courses, etc. When the transfer of knowledge can be carried out, the business owned can continue to grow, and the disability can recruit other people to work in the business, it does not have to be run by the person with disability alone. As for businesses engaged in handicrafts, they can increase marketing so that they can expand the scope of Gunungkidul's business. When the business is getting bigger, the owner does not have to run his own business, but can only give orders. This will help disability performance but still contribute to moving the wheels of the economy in Gunungkidul Regency and also in Indonesia.

The progress of disability in its business cannot be taken for granted, but there must also be government intervention, by Government Regulation No. 70 of 2019 which regulates the implementation of respect, protection, and fulfillment of the rights of persons with disabilities as part of the implementation of national and regional development. One form of fulfillment of disability rights is to get guidance and support from the government, including in developing their business. In general, the government already must help the community in business development, especially programs that can be carried out by the MSME Service, supported also by the Social Service which has direct responsibility for dealing with people with disabilities.

Cooperation between government agencies to support the advancement of disability will be very meaningful for the development of businesses run by people with disabilities. Entrepreneurial development also needs to be done to form independent and productive disabled people, not only for themselves but also useful for helping others.

\section{Analysis of the Government's Contribution to Business with Disabilities}

The role of the government in the welfare of persons with disabilities, especially in the economy. People with disabilities are expected to be independent in running their economy so that the government can contribute directly to the businesses run by people with disabilities. Representatives from the government in the business sector are the MSME Service. The role of the MSME Service in Gunungkidul Regency towards disability in Gunungkidul Regency is quite good. Several things have been done by the UMKM Office of Gunungkidul Regency to support welfare, including and providing special stands in exhibition events in the region or certain events on big days such as expos held for the operation of Cooperative Day.

There are still many contributions that can be made from the UMKM Service, not only limited to those who participate in the expo. Data on disability in Gunungkidul district that runs a business has not been specifically implemented, so this has an impact on the lack of maximum 
business assistance from the service for persons with disabilities. Most of the assistance that has been given is related to making a craft that can be traded. Making a craft is something that can be taught, however, not all people with disabilities have the talent to make a craft, so alternative businesses that can be run with disabilities must be provided. The alternative can be directed at the UMKM Office, so that people with disabilities can run a more diverse business. If you look at the types of businesses that have been run by people with disabilities in Gunungkidul Regency, the respondents in this study have varied, but still need assistance from the UMKM Office.

The assistance expected by persons with disabilities who have obtained a business includes marketing assistance, assistance in improving product quality, and also assistance to be able to access capital. Persons with disabilities who run businesses expect assistance from the government, especially in advancing their products. In addition, persons with disabilities also expect regular assistance and regular monitoring. When these activities can be carried out by the government represented by the government, welfare will increase and if there is an obstacle, disability will be achieved with the relevant agencies.

Assistance or other contributions that the government can make is by guiding persons with disabilities regarding the leading business sectors in Gunungkidul Regency so that groups of people with disabilities can improve their skills by adjusting the superior sector. That way, it will be easier for the disabled group, because it is also supported by adequate resources, as well as adequate infrastructure.

\section{CLOSING}

\section{Conclusion}

The conclusions of this study can be described as follows.

1. The types of businesses run by people with disabilities in Gunungkidul Regency are mostly services (shaving, massage, and sewing), handicrafts, printing, and culinary services. The type of business carried out is by the advantages possessed by Gunungkidul Regency, namely the agricultural, industrial, and service sectors.

2. The government, represented by the Gunungkidul Regency MSME Service, has already involved disabilities in the expo activities that were held, but the disabled expect more roles from the service for business assistance, starting from improving product quality, marketing to capital.

\section{Research Limitations}

The limitations of this study are as follows.

1. Persons with disabilities who become respondents are still very limited because there is no complete data from the office regarding the disability who runs a business.

2. Research that can be carried out during the covid-19 pandemic, thereby limiting the space for researchers to meet with disabilities directly and directly.

\section{BIBLIOGRAPHY}

Arifin, A., \& Muta'ali, L. (2016). Distribusi Perekonomian Wilayah dan Sektor Unggulan di Kabupaten Gunungkidul. Jurnal Bumi Indonesia, 5(4), 3-10.

Arzul, H. F., Khaidir, A., \& Mubarak, A. (2019). Peranan Dinas Tenaga Kerja dan Perindustrian dalam Meningkatkan Kesempatan Kerja Bagi Penyandang Disabilitas. JESS (Journal of Education on Social Science), 3(2), 135. https://doi.org/10.24036/jess/vol3iss $2 / 134$ 
Djaelani, A. R. (2013). Teknik Pengumpulan Data dalam Penelitian Kualitatif. Majalah Ilmiah Pawiyatan, Volume XX Nomor 31.

Ginintasasi, R. (2013). Kesadaran Sigmund Freud. UPI EDU:

http://file.upi.edu/Direktori/FIP/JUR._PSIKOLOGI/195009011981032-

RAHAYU_GININTASASI/Kesadaran_Sigmund_Freud_\%5BCompatibility_Mode\%5D .pdf.

Ginintasasi, R. (n.d.). Kesadaran. UPI EDU:

http://file.upi.edu/Direktori/FIP/JUR._PSIKOLOGI/195009011981032-

RAHAYU_GININTASASI/Kesadaran_Carl_Jung_\%5BCompatibility_Mode\%5D.pdf.

Khusnah, B. (2017). Pelaksanaan Inventarisasi Barang Milik/Kekayaan Negara Di Kantor Komisi Pemilihan Umum (KPU) Kabupaten Kulon Progo [Universitas Negeri

Yogyakarta.]. http://journal.student.uny.ac.id/ojs/ojs/index.php/adp-s1/article/view/8747

Khusnah, B. (2017). Pelaksanaan Inventarisasi Barang Milik/Kekayaan Negara Di Kantor Komisi Pemilihan Umum (KPU) Kabupaten Kulon Progo [Universitas Negeri

Yogyakarta.]. http://journal.student.uny.ac.id/ojs/ojs/index.php/adp-s1/article/view/8747

Malikah. (2013). Kesadaran diri proses pembentukan karakter islam. Jurnal Al-Ulum, Vol. 13(No.1), 129-150.

Merfianti, A. (2015). Uji Keabsahan Data dalam Penelitian Kualitatif. In 07 Februari. Universitas Negeri Makassar: http://penalaran-unm.org/artikel/penelitian/409-ujikeabsahan-data-dalam-penelitian-kualitatif.html.

Mirathan, A. (2013). Identifikasi Potensi Ekonomi Masyarakat Kabupaten Tapin Tahun 2009. Bappeda Tapin.

Panggiarti, E. K., \& Setyawan, S. (2019). Rancangan Model Pemberdayaan Umkm Untuk Mempertahankan Kearifan Lokal Di Kabupaten Magelang. Monex : Journal Research Accounting Politeknik Tegal, 8(1), 142. https://doi.org/10.30591/monex.v8i1.1087

Palewa, D. A. (2013). Motif Penggunaan dan Interaksi Sosial di Twitter (Studi Deskriptif Kualitatif Pada Mahasiwa Ilmu Komunikasi FISHUM UIN Sunan Kalijaga Yogyakarta). Universitas Islam Negeri Yogyakarta.

Puspitaningtyas, Z., Wahono, P., \& Poernomo, D. (2013). Laporan Akhir Penelitian Hibah Bersaing (Issue November 2014).

Putri, Z. E. (2018). PEMANFAATAN JARINGAN SOSIAL DALAM PENGEMBANGAN USAHA OLEH PELAKU UMKM (Studi Kasus: 8 Pelaku UMKM pada Sentra Makanan Rendang di Kelurahan Sungai Durian, Kecamatan Lamposi Tigo Nagari, Kota Payakumbuh). JSSH (Jurnal Sains Sosial Dan Humaniora), 2(1), 1. https://doi.org/10.30595/jssh.v2i1.2171

Rachbini, D. J. (2001). Pembangunan Ekonomi \& Sumber Daya Manusia. Gramedia Widiasarana Indonesia.

Restiatun, R. (2009). Identifikasi Sektor Unggulan Dan Ketimpangan Antarkabupaten/Kota Di Provinsi Daerah Istimewa Yogyakarta. Jurnal Ekonomi \& Studi Pembangunan (Jurusan 
Ekonomi Pembangunan Fakultas Ekonomi Universitas Negeri Malang), 10(1), 77-98. https://doi.org/10.18196/jesp.10.1.1279

Rofiq, F., \& Edward, M. Y. (2019). KINERJA MANAJEMEN MODAL KERJA BERDASARKAN GENDER DAN JENIS USAHA Program Studi Manajemen, Fakultas Ekonomi dan Bisnis , Universitas Islam Nahdlatul Ulama Jepara E-mail : edward @ unisnu , ac , id. 11(2), 165-173.

Rosita, Kusasih, I. A. K. R., \& Istiyanto, B. (2017). PERBAIKAN PENGELOLAAN UMKM GUNA PENGEMBANGAN USAHA MIKRO. JURNAL PENGABDIAN DAN PEMBERDAYAAN MASYARAKAT, 1(1).

Salamah, U. (2015). Pemanfaatan Sabda Dalam Inventarisasi Aset Daerah Guna Mendukung Penerapan E-Government Di Badan Pengelolaan Keuangan Dan Aset Daerah Kabupaten Lamongan. Universitas Negeri Surabaya Fakultas Ekonomi Jurusan Pendidikan Ekonomi Prodi Pendidikan Administrasi Perkantoran, 15.

Sudira, P. (2009). Studi Mandiri Grounded Theory. Yogyakarta : UNY, 1-29.

Surwanti, A. (2014). Model Pemberdayaan Ekonomi Penyandang Disabilitas Di Indonesia. In Jurnal Manajemen Bisnis Universitas Muhammadiyah Yogyakarta (Vol. 5, Issue 1). https://doi.org/10.18196/mb

Surwanti, A., \& Hindasah, L. (2013). Model Pemberdayaan Ekonomi Penyandang Disabilitas di Indonesia (Working Paper).

Tjahjanti, P. H., Sumarmi, W., Widodo, E., Syamharis, R., Zamroni, S. A., \& Prakoso, D. I. (2018). Strategi Membantu Wirausaha Disabilitas Untuk Memberdayakan Ekonomi Secara Berkelanjutan. Abdimas Pedagogi, 2(1), 37-43.

Y Hadi, Kurniawan, Y., \& Irawan, R. (2017). Perancangan Alat Ukur Produktivitas UMKM Menggunakan Metode American Productivity Centre. Journal of Chemical Information and Modeling, 53(9), 1689-1699.

Undang-Undang No.8 Tahun 2016 tentang Penyandang Disabilitas., (2016).

Peraturan Presiden Nomor 98 tahun 2014, (2014). 